\title{
OBSERVATIONS ON THE DEALFISH, TRACHIPTERUS ISHIKAWAI JORDAN \& SNYDER, WITH DESCRIPTIONS OF ITS PARASITES
}

\author{
AUTHOR(S):
}

Nishimura, Saburo

\section{CITATION:}

Nishimura, Saburo. OBSERVATIONS ON THE DEALFISH, TRACHIPTERUS ISHIKAWAI JORDAN \& SNYDER, WITH DESCRIPTIONS OF ITS PARASITES. PUBLICATIONS OF THE SETO MARINE BIOLOGICAL LABORATORY 1963, 11(1):75-100

\section{ISSUE DATE:}

1963-07-20

URL:

http://hdl.handle.net/2433/175325

RIGHT: 


\title{
OBSERVATIONS ON THE DEALFISH, TRACHIPTERUS ISHIKAWAI JORDAN \& SNYDER, WITH DESCRIPTIONS OF ITS PARASITES
}

\author{
SABURO NISHIMURA \\ Japan Sea Regional Fisheries Research Laboratory, Niigata
}

With Plate II, 7 Text-figures and 6 Tables

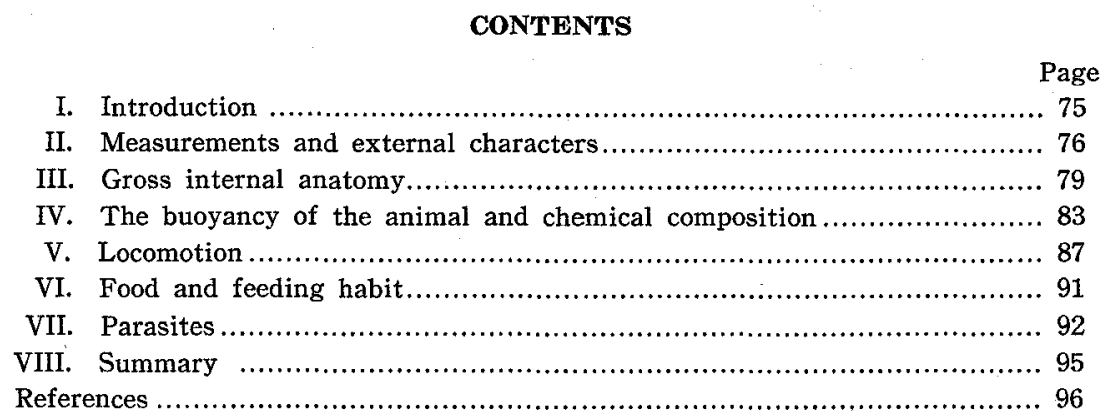

\section{Introduction}

Since first described by JoRdAN and SNYDER in 1901, the dealfish, Trachipterus ishikawai (Teleostei : Lampridiformes), had until recently been regarded as one of the rarest species among marine teleostean fishes; throughout the subsequent fifty years to the original report, occurrence of this peculiar-formed species had been recorded from not more than eleven localities in the entire Japanese waters.

Lately, however, I suggested (NISHImura 1962a) a possibility that the number of immigrating dealfish to the Japanese waters might have recently been augmented considerably, because there was a notably increased number of specimens reported from various localities, particularly from the Japan Sea coasts of Honshu, during the last several years; and at present the dealfish is by no means said to be a very rare species at least so far as the western side of Honshu is concerned. In these districts, the fish are mostly drifted ashore dead or exhausted, but at certain localities they are entrapped by various types of fishing nets.

Publ. Seto Mar. Biol. Lab., XI (1), 1963, (Article 4) 
In the middle of March, 1962, Messrs. Hiroshi Fukataki and Muneo Okiyama, my colleagues at the Japan Sea Regional Fisheries Research Laboratory visited Waki, a set-net fishing village of Sado Island, for the purpose of tagging the chab mackerel, Pneumatophorus japonicus. During their stay at this island in the eastern Japan Sea, they very fortunately had a chance to observe three individuals of the dealfish entrapped in the net. Through the courtesy of these gentlemen, two of the three specimens were forwarded to me for closer study. They were fresh specimens of a male and a female.

The dealfish, because of the secret life it would lead at a midwater depth in the ocean (Nishimura 1962a), remains unrevealed at all until now of its mode of life including behavior, locomotion, food habits, etc. The limited number of fresh and complete specimens hitherto available to us has also been keeping us from studying these problems from the anatomical and physiological standpoints.

In the present paper, it is intended to give the results of observations made on the specimens mentioned previously and to consider on some aspects of the biology of this strange mesopelagic teleost on the basis of the results obtained. In addition, a short description will be made of two species of parasitic helminths from the specimens, both of which seem respectively to be found for the first time in the dealfish.

My heartfelt thanks are due to Messrs. H. Fukataki and M. Oкiyama, who were kind enough to submit the precious material at my disposal. I am also indebted to Misses Takeko Kasahara and Atsuko Honda of the Japan Sea Regional Fisheries Research Laboratory for their willing help rendered to me respectively in analyzing chemical constituents of the fish and in preparing mounted specimens of the cestode parasite. Mr. Takemi Tsuda of the ShinMinato Chubu Junior High School and Mr. Chuichi Araga of the Aquarium of the Seto Marine Biological Laboratory kindly sent me unpublished informations. I am grateful to Mr. Gendi KatoH of the Japan Sea Regional Fisheries Research Laboratory who read the manuscript. My last but not least gratitude is extended to Dr. Takasi Tokioka of the Seto Marine Biological Laboratory for his kindness in giving me facilities for publishing the present paper.

\section{Measurements and External Characters}

The material upon which the present descriptions are based are a male and a female specimen caught respectively on March 16 and 19,1962, by the set-net at Waki (和木) in Sado Island. Both specimens were immediately packed in a snow-cold box and shipped to our laboratory. in Niigata. Fortunately, they arrived in a quite fresh state and without delay were placed under measurements and observations. 


\section{Trachipterus ishikawai JORDAN \& SNYDER \\ (Japanese name: Sakegashira)}

(Plate II)

Trachypterus ishikawae JORDAN \& SNYDER 1901: 310 (original description; type locality, Tokyo Bay). EBINA 1934: 530 (record at Shimizu in Shizuoka Prefecture, with a general account on the taeniosome fishes). KAMOHARA 1950:282 (description and distribution).

Trachypterus ishikawai KAMITA 1962: 20 (records in Tottori and Shimane Prefecture).

Trachipterus ishikawae MisHio 1936: 127 (description on the same specimen reported by EBINA 1934). Matsubara $1947: 458$ (description and distribution). YaNAI 1950:59 (occurrences in San'in district). HoNDA 1960: 114 (records in Ishikawa Prefecture).

Trachipterus ishikawai MATSUBARA 1955: 462 (description and distribution, with a new record at Maizuru). Kuroda 1957: 462 (record at Numazu). TomiYamA \& ABE 1958: 231 (description and distribution, with a colored figure). TSUDA 1959:23 (records in Toyama Bay, with morphological and ecological notes). NISHIMURA 1960c:214 (records in Niigata and Yamagata Prefecture). Nishimura \& MizUSAWA 1962: 33 (additional records in Niigata Prefecture). Nishimura 1962a: 51 (records in the Japanese waters compiled).

Trachypterus sp. (Sakagashira) MORI 1952: 77 (records at Pusan and Pohang, Korea).

\section{Measurements}

Measurements of body parts and meristic characters were made mainly according to the standard way given by Matsubara (1955). The results are shown on Table 1.

\section{Description}

The following description is based in the main on the female specimen; the characters of the male specimen are given in parentheses only when any individual variations are noted.

Body elongate and compressed; greatest body depth just behind pectoral insertion (about middle of preanal length), hind part of body gradually narrowing toward caudal peduncle. Head relatively small. Gape rather short, directed obliquely upward and forward; the upper jaw very protractile. Lips rather weekly developed but fairly solid. Eye lateral and quite large, round in outline, occupying the middle third of head length and within the upper half. Iris very broad. Pupil oval in outline, its longer axis inclined inferoposteriorly*. Maxillary well and opercular bones fairly well developed; both are coarsely ossified and provided with radiating lines on the surface. Sharplypointed and irregularly-sized teeth present, numbering 4-3 (6-6) on dentary, 4-4 (3-4) on premaxillary, 2 (3) on vomer [in a longitudinal row], and 4-3 (4-1) on palatine; all bent toward pharynx. Gill-opening considerably large. Branchiostegal membrane connected with isthmus. Gill-lamellae long, well

* The same feature was observed and figured also by HuTToN (1961) for the oarfish from the Gulf of Mexico, Regalecus glesne (Ascanius), akin to the dealfish. However, the oarfish from the Japanese waters, viz. R. russellii (SHAw), has a round pupil (Kuroda 1947; Mori 1956; Nishimura 1960a). 
Table 1. Results of measurements on the two fresh specimens of the dealfish studied in the present work.

\begin{tabular}{|c|c|c|}
\hline & Male specimen & Female specimen \\
\hline Standard length & $1208 \mathrm{~mm}$ & $1331 \mathrm{~mm}$ \\
\hline Weight & $2604 \mathrm{~g}$ & $4011 \mathrm{~g}$ \\
\hline Volume & (Not measured) & $3867 \mathrm{cc}$ \\
\hline Vertebrae & (Not counted) & 70 \\
\hline Dorsal fin-ray & 135 & ca. 149 \\
\hline Pectoral fins* & $i+11(1)-i+.11\left(r_{0}\right)^{* * *}$ & $i+12(1)-i+.12(\text { r. })^{* *}$ \\
\hline Caudal fin & (Dropped off) & (Dropped off) \\
\hline Gill-rakers on 1 st $\operatorname{arch} \dagger$ & $11-12$ & $11-12$ \\
\hline Branchiostegal rays & $6-6$ & $6-6$ \\
\hline \multicolumn{3}{|l|}{ In standard length: } \\
\hline Head length & 8.3 & 7.8 \\
\hline Greatest body depth & 7.0 & 6.6 \\
\hline Body depth at pectoral insertion & 7.4 & 7.2 \\
\hline Body depth at anus & 8.5 & 7.7 \\
\hline Least caudal peduncle depth & 110 & ca. 102 \\
\hline Preanal length & 1.8 & 1.8 \\
\hline \multicolumn{3}{|l|}{ In head length: } \\
\hline Snout length & 3.5 & 3.2 \\
\hline Eye diameter & 3.0 & 3.3 \\
\hline Interorbital space & 4.7 & 4.7 \\
\hline Length of longest dorsal ray & 2.9 & 2.8 \\
\hline Length of longest pectoral ray & 2.5 & 2.4 \\
\hline Length of base of pectoral fin & 11.2 & 12.2 \\
\hline \multicolumn{3}{|l|}{ In eye diameter : } \\
\hline Longer diameter of pupil & 2.2 & ca. 1.8 \\
\hline Shorter diameter of pupil & 3.4 & ca. 3.9 \\
\hline Diameter of lens & 3.6 & 3.4 \\
\hline
\end{tabular}

* The foremost ray is quite short.

** 1.-left side, r. - right side. This arrangement is retained throughout the whole similar representations.

† Those on the outer side, including rudimentary ones, were counted.

developed. Gill-rakers poorly developed, cartilaginous, each provided with a few pointed spinules on the inner surface [as in the outer gill-rakers] or on the distal portion [as in the inner gill-rakers] (Text-fig. 6). Pseudobranchiae fairly well developed. Upper pharyngeal teeth excellently formed: 4 or 5 sharply-pointed, canine-like teeth arranged in a longitudinal row and rapidly increasing the size backward on each of the three pairs of pharyngeal plates [the posterior-most one on the first and the second pair of pharyngeal plates are particularly powerful], and all inclined strongly toward pharynx. Single dorsal fin remarkably well developed, begins at a vertical a little before the 
posterior margin of eye, and occupies the whole dorsal edge of trunk and tail. Anal fin absent. [Caudal fin torn off in both specimens]. Pectoral fin relatively small, lanceolate, inserted just behind interopercle and near ventral margin of trunk, with base almost horizontal. Pelvic fin absent. Dermis covering the body surface is horny, fairly thick and tough. Lateral line spiny and remarkably developed, starting from above eye and gradually descending along the lower profile of abdomen to the extremity of caudal peduncle. Anus situated a little behind the middle of body*, displaced slightly to the left side from the midventral line. The surface of skin is studded with numerous flattopped tubercles; the most prominent ones lie in a series along the cutting edge of abdomen, more or less sharply tipped and strongly inclined forward. Rather well-developed tubercles also found arranged in short transverse vertical rows on the surface around the basement of dorsal fin. Scales present, relatively large in size and elliptical in shape, but exceedingly thin, arranged in a longitudinal direction and not imbricated.

Colour of fresh specimens

Body bright silvery without any particular markings; darkened toward belly by superficial melanophores. Opercle, subopercle and interopercle appear dark purplish**. A longitudinal black stripe runs from frontal region down to the tip of lower jaw. Iris platinum-colored and marked along its periphery by a scarlet loop***. Dorsal and pectoral fins pinkish.

\section{Gross Internal Anatomy}

Observations were made on the visceral organs, vertebral column, musculature and fin in correlation with their taxonomical and ecological significance. Visceral organs (Text-fig. 1)

Peritoneal cavity rather small and laterally compressed. Peritoneum pearly white. No fat bodies. Oesophagus short and broad, with moderately thick wall. Stomach elongated, consisting of long corpus, relatively long blind sac and short pyloric part; its wall thick, with well defined 8 or 9 longitudinal folds on the inner mucous membrane. Tip of blind sac lies nearer pyloric valve than anus. Duodenum curves in U-shape. Intestine runs straightly

* Several authors, MAtsubara (1947), Tomiy AmA \& ABE (1958) and others, state that the anus is situated a short way before the middle of body; but so far as the present two specimens are concerned, it is apparently behind the middle of body. This is also noted by TSUDA (1959), who attests that in all of the fourteen specimens he examined the anus is invariably situated behind halfway of body length.

** There are distributed melanophores on the epithelial layer lining the sides and bottom of buccal cavity, and these give a dark purplish tint to the semi-transparent opercular bones.

*** Messrs. Fukataki and Oxiyama, who had fortunately a chance to observe the entrapped dealfish still living and swimming around in the net, told me that they were much impressed by this scarlet loop on the iris so distinctive in water. 


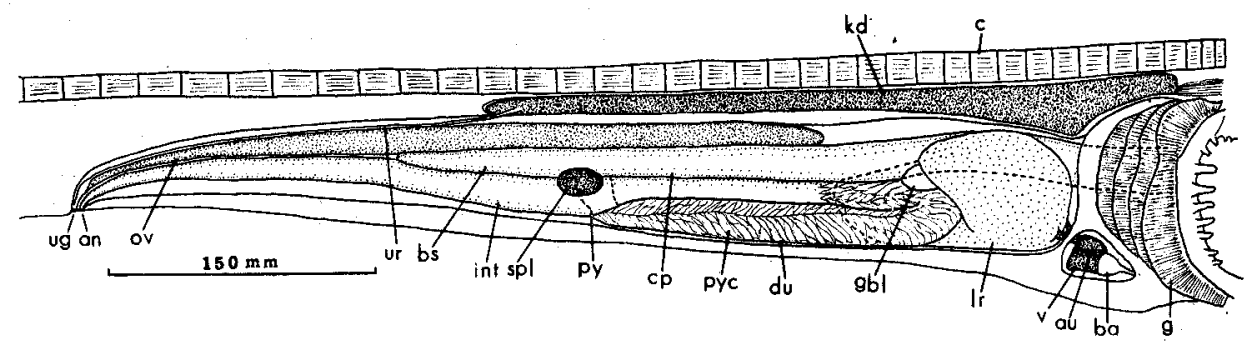

Text-fig. 1. Diagrammatic representation of the arrangement of visceral organs in the dealfish an-Anus; au-Auricle; ba-Bulbus aortae; bs-Blind sac of stomach; c-Centrum of vertebra ; $\mathrm{cp}$-Corpus of stomach; du-Duodenum; $\mathrm{g}$-Gill ; gbl-Gall-bladder ; int-Intestine; kd-Kidney; lr-Liver; ov-Ovary; py-Pyloric part of stomach; pyc-Pyloric appendage ; spl-Spleen ; ug-Urogenital orifice ; ur-Ureter ; v-Ventricle.

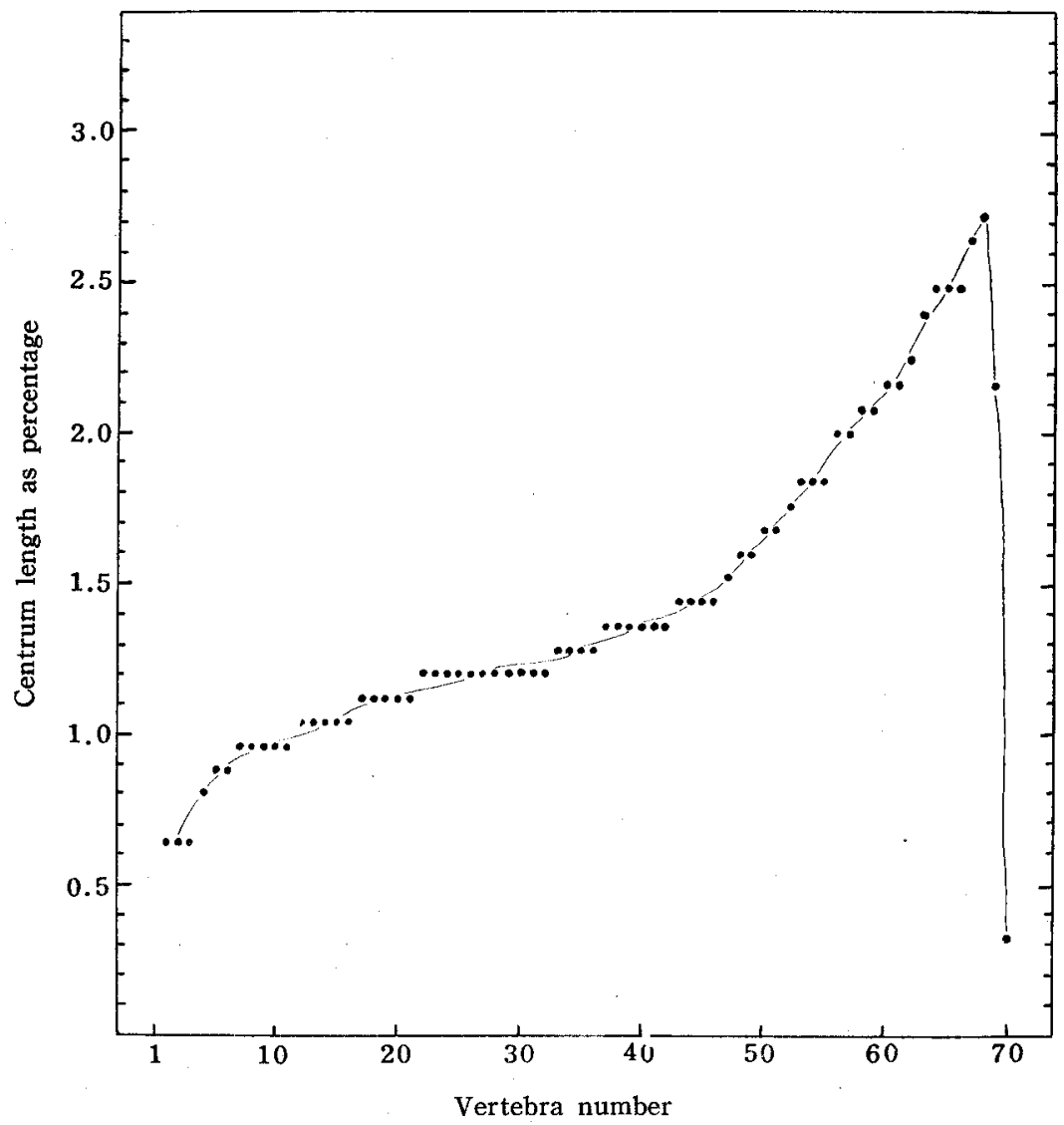

Text-fig. 2. Vertebral length curve for the dealfish. 
backward, its wall exceedingly thin. Pyloric appendages short and numerous, arranged on either side of duodenum. Liver relatively small but thick, consists of two lobes, the left lobe much thicker than the right one, wrapping the

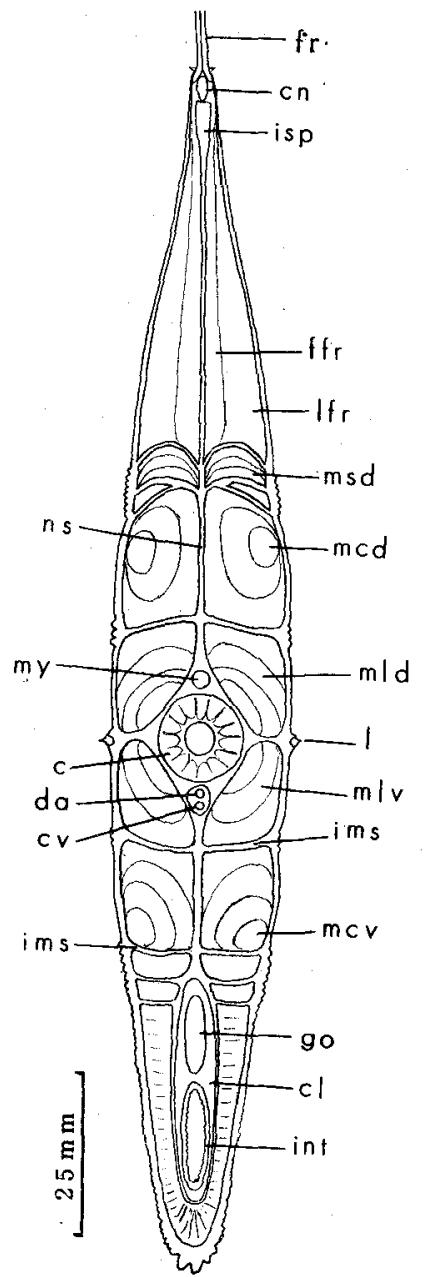

Text-fig. 3. Diagrammatic representation of a cross section of the posterior trunk region in the dealfish. $\mathrm{c}$-Centrum of vertebra ; $\mathrm{cl}$-Coelom ; $\mathrm{cn}$-Cartilaginous nodule (through which the dorsal fin-ray is articulated with the interspinous bone); $\mathrm{cv-Caudal} \mathrm{vein;}$ da-Dorsal aorta ; ffr-Flexor muscle of dorsal fin-ray ; fr-Dorsal fin-ray ; go-Gonad ; ims-Intermuscular septum; int-Intestine; isp-Interspinous bone; 1-Lateral line; If $\mathbf{r}$-Levator muscle of dorsal fin-ray; mcd-Musculus carinatus dorsalis ; mcv-Musculus carinatus ventralis ; mld-Musculus latero-dorsalis; mlv-Musculus latero-ventralis; msd-Musculus supracarinalis dorsalis; my-Spinal code; ns-Neural spine.

corpus of stomach and the winding portion of duodenum from below. Gallbladder small, not much elongated, and located between the corpus of stomach and duodenum. Spleen oval-shaped, and located along the pyloric part of 
stomach. Ovaries consist of paired, extremely elongated lobes*. Swimbladder quite missing. Kidney relatively large and thick, occupying the anterior twothirds of the dorsal side of body cavity, its anterior part dilated.

Vertebral column and trunk musculature

Vertebral column rather robust, but poorly ossified and very fragile. Vertebrae, 70 in number**, steadily increase the centrum length backward to the antepenultimate vertebra (Text-fig. 2); in the postanal portion, vertebrae are situated respectively at the location corresponding to a couple of lateral line plates. Trunk musculature is fairly developed though not solid, all consisting

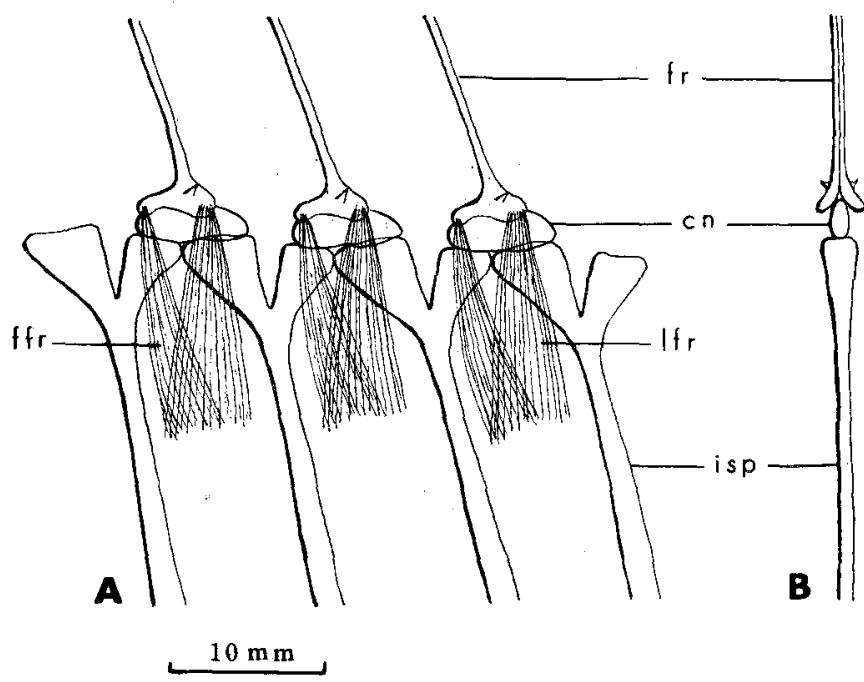

Text-fig. 4. Diagrammatic representation of the articulation between the dorsal fin-rays and the interspinous bones in the dealfish. A. Lateral view; B. Frontal view. cn-Cartilaginous nodule; ffrFlexor muscle of fin-ray (the lower part omitted); fr-Dorsal fin-ray; isp-Interspinous bone; lfr-Levator muscle of fin-ray (the lower part omitted).

of "white muscle" with reduced formation of muscular fibers; myomeres separated from one another by fairly-developed Ligamenta intermuscularia. The principal part of the lateral muscular system consists as usual of four pairs of longitudinal bundles: Musculus latero-dorsalis, M. latero-ventralis, $M$. carinatus dorsalis and M. carinatus ventralis. Enveloping these lateral muscle bundles, are well formed Perimysia externa; these are united inward with the Periosteum of vertebrae and outward with the dermis to form intermuscular septa (Text-fig. 3). The body musculature is gradually diminished posteriorly till it reaches the caudal peduncle where it becomes quite insignificant.

\footnotetext{
* In the studied female specimen, the ovarian eggs were in an immature resting stage.

** Mr. T. Tsuda tells me in a personal communication of April 1962 that one of his specimens (144 cm in length) has 69 vertebrae.
} 
Rays and other appendages of dorsal fin

Particularly well-developed dorsal fin bears long flexible rays which are neither articulated nor branched; rays are jointed to interspinous bones through the intermediary of a cartilaginous nodule in a unique way (Text-fig. 4). The interspinous bones are $\mathrm{Y}$-shaped with short stout arms and a long slender stem; the posterior arm comes in contact with the anterior arm of next bone, the two arms are bound together by ligament and their distal ends are slightly rounded on the side of contact to form a sort of shallow cavity, where is fastened the ligament holding an ovoidal cartilaginous nodule. Upon the nodule is perched the saddle-shaped, expanded proximal end of the dermal fin-ray. In every interspace between the long stems of interspinous bones, are accomodated the levator and flexor muscles of fin-ray, both consisting of "red muscle"* . The levator, particularly well developed, arises from the side of the anterior part of pedate proximal end of each fin-ray and is generally splitted into two and on some occasions three branches ventrally in the trunk region, and the branches are attached to the tendonous septum of Musculus supracarinalis dorsalis. The flexor, on the other hand, is originated at the posterior part of the proximal end of each fin-ray, runs downward between the right and left levator muscles, and terminates likewise at the tendonous septum of M. supracarinalis dorsalis.

\section{The Buoyancy of the Animal and Chemical Composition}

As mentioned already, the dealfish entirely lacks the swimbladder; this must be noted in the viewpoint of the buoyancy, because the teleostean swimbladder is believed principally to function as an important hydrostatic organ (Jones 1951, 1957). The body parts of a teleost deprived of swimbladder, fat and viscera have a considerably larger density than the normal sea water (TAYLOR 1921); thus, the fish without an inflated swimbladder nor a prominent amount of stored fat will continuously fall down through the water unless some compensatory effort is made against the sinking. This is just the case with the bladderless teleosts of typical neritic or littoral habitat such as the mackerel, Scomber scombrus, the plaice, Pleuronectes platessa, and the shanny, Blennius pholis, all showing a large sinking factor (generally more than 1030 ; see Table 2). In certain bathypelagic fishes, on the other hand, it is cleared that the swimbladder is converted into a fat-storing organ (MARSHALL 1950; Jones \& MARShall 1953; Iwai 1959), and without doubt this must be an effectual modification for the fishes to prevent the undue loss of energy secreting gas

\footnotetext{
* When the epidermis with guanine-deposited cells is more or less worn out by friction, these muscles can be seen, without any dissection, as dark red transverse bands through the semitransparent dermis layer covering the basement of the dorsal fin.
} 
Table 2. Volume of the swimbladder, density and sinking factor in some marine teleosts.

\begin{tabular}{l|c|c|c|l}
\hline \multicolumn{1}{c|}{ Species } & $\begin{array}{c}\text { Volume of } \\
\text { swimbladder } \\
\text { as percentage }\end{array}$ & Density & $\begin{array}{c}\text { Sinking } \\
\text { factor }\end{array}$ & \multicolumn{1}{|c}{ Sources } \\
\hline Neritic: & & & & \\
Mugil auratus & 5.6 & 1.010 & 980 & PLATTNER (1941) \\
Monacanthus cirrhifer & 5.2 & 1.022 & 996 & AKITA (1936) \\
Fundulus heteroclitus & 5.0 & 1.023 & 1003 & BLACK (1948) \\
Crenilabrus melops & 4.9 & 1.033 & 1006 & PLATTNER (1941) \\
Scomber scombrus & Absent & 1.070 & 1043 & MAGNAN (1929) \\
Littoral: & 1.1 & 1.050 & 1023 & JONES (1951) \\
Ciliata mustela & Absent & 1.066 & 1039 & DELAROCHE (1809) \\
Pleuronectes platessa & Absent & 1.070 & 1042 & PLATTNER (1941) \\
Blennius pholis & Absent & 1.077 & 1050 & LOWNDES (1941) \\
Cottus bubalis & Absent & 1.084 & 1055 & PLATTNER (1941) \\
Callionymus lyra & & & & \\
Mesopelagic: & Absent & 1.037 & 1011 & Present article \\
Trachipterus ishikawai & & & & \\
Bathypelagic: & Absent & 1.033 & 1005 & DENTON \& MARSHALL (1958) \\
Gonostoma elongatum & Absent & 1.040 & 1012 & DENTON \& MARSHALL (1958) \\
Xenodermichthys copei & A & &
\end{tabular}

$\dagger$ (Density of the animal)/(Density of the surrounding water) $\times 1000$

for the bladder under so high water pressure and to reduce to a certain extent the density of the animal.

What is then the matter with the dealfish entirely without swimbladder? To answer the question, an attempt was made to estimate the density and sinking factor of this mesopelagic teleost.

Density and sinking factor

The female specimen was placed under the density determination: the weight was measured in gram by a balance and the volume was defined by reading the volume of displaced water in cubic centimeter, immersing the whole fish body in a large water-filled vessel. The results thus obtained are shown on Table 1. The density of the animal is then calculated to be 1.037*. As this fish is considered to be an inhabitant of the Central Water Mass of the ocean like the oarfish (NISHImura 1962a, 1962b), 1.026** may be appropriate for the density of the environmental sea water; thus, the sinking factor for the dealfish is calculated as 1011, as shown on Table 2.

One may be surprised at too small a density value, viz. within $1.1 \%$ of

*,** Both are the values under normal atmospheric pressure. The values in situ must be somewhat (up to $0.2 \%$ ) larger. However, the volume change of this fish under varying pressure seems to be nearly the same as that of the water, since the utmost constituent of the dealfish is water as is shown later, and thus the calculated sinking factor can safely be taken as the value in situ. 
neutral buoyancy, being indicated by this bladderless fish. This stands in a marked contrast to the values, mostly with in $4-5 \%$ of neutral buoyancy, obtained for the neritic and littoral bladderless species, and it is rather near the situation found among the neritic teleosts which are provided with a gas-filled swimbladder occupying approximately $5 \%$ of the total body volume (Table 2). This is truly a remarkable fact about the dealfish, and it reminds us of an interesting work by Denton \& Marshall (1958), which revealed that the bathypelagic teleosts, Gonostoma elongatum and Xenodermichthys copei, are keeping roughly the neutral buoyancy though they are devoid of gas-filled swimbladder (Table 2), and successfully showed through chemical and radiographical investigations that the marked reduction in density is achieved by a poor ossification in skeletal system as well as a reduction in muscular development.

Analyses of chemical components

Chemical analyses were made for muscles and bones, the two principal components of the dealfish body. Samples for the former were taken from Musculus latero-dorsalis in the trunk region, and those for the latter from vertebrae (XVI to XIX), clavicle and urohyal. Moisture, ash, crude fat and total nitrogen for proteins were determined for the muscle samples, and moisture and ash alone for the bone samples.

Procedures adopted are as follows :

Moisture $4.5-10 \mathrm{~g}$ prepared samples were placed in glass or porcellain weighing dish with cover and dried in oven at $100-105^{\circ} \mathrm{C}$ to minimum weight.

Ash Dried samples thus obtained were burned in electric oven at $550 \pm 20^{\circ} \mathrm{C}$ for 24 hours, cooled in desiccator, and promptly weighed.

Crude fat 5-100 g prepared samples were ground together with anhydrous sodium sulphate and extracted with cold ether 6-7 times. The extract was then removed of ether, kept in desiccator, and weighed.

Total nitrogen and proteins The total nitrogen was determined using the micro-Kjeldahl method. In computing protein amount, the conventional factor of 6.25 was adopted to make it easier to compare the result with those shown in previous literature, though Love (1957) mentions that in fish the factor 6.025 is much more appropriate to obtain the true value.

The results of the chemical analyses are given on Table 3.

Table 3. Results of chemical analyses of the dealfish. Values are given as percentages of wet weight; those in parentheses are mean values.

\begin{tabular}{ll|c|c|c|c|c}
\hline \hline \multicolumn{1}{c|}{ Parts } & Moisture & Ash & Crude fat & Protein & Residue \\
\hline $\begin{array}{l}\text { Musculus } \\
\text { latero-dorsalis }\end{array}$ & \} & 88.22 & 0.995 & $\begin{array}{c}0.0930-0.118 \\
(0.103)\end{array}$ & $\begin{array}{c}8.50-8.61 \\
(8.56)\end{array}$ & $(2.12)^{*}$ \\
$\begin{array}{l}\text { Vertebra } \\
\begin{array}{l}\text { Clavicle and } \\
\text { urohyal }\end{array}\end{array}$ & 91.91 & 3.09 & - & - & $5.00^{* * *}$ \\
\end{tabular}

* Carbohydrates and volatile matter.

** Organic matter. 
Table 4. Chemical components of some neritic and epipelagic teleosts.

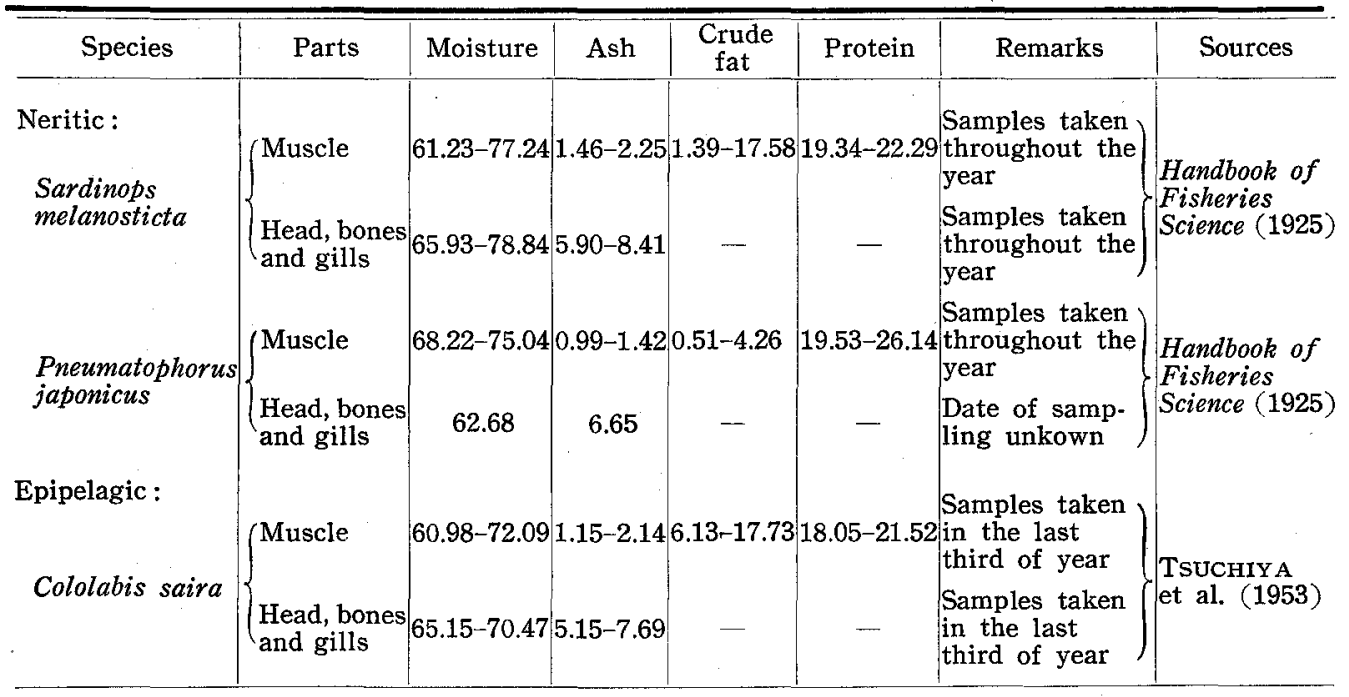

For the purpose of comparing the results with the conditions in other marine teleosts, Table 4 is prepared to show the results of analyses made by previous workers on three species of the representative teleosts of the neritic and epipelagic environments. It is regrettable, however, that no data are given for the bone alone; therefore the figures for the combined samples of bones, head and gills are shown on the table out of necessity.

It is clear that the dealfish contains more water, less ash (in muscles and bones) and remarkably lesser amounts of crude fat* and proteins (in muscles) as compared with the three members of the neritic and epipelagic environments; and it may be recognized that such a chemical composition of the dealfish is effectual to reduce the body density through the poor ossification of skeletal system and the reduced muscular development. This is just the same as what Denton \& Marshall (1958) have observed in Gonostoma elongatum and Xenodermichthys copei. It is thus considered that such a modification is an adaptation generally found in the bladderless meso- and bathypelagic fishes to overcome the delicate buoyancy problem.

* An attention is to be paid to the remarkably low content of fat in the muscle of the dealfish. Once, UCHIDA (1956) mentioned as regards the oarfish with a morphological structure very similar to the dealfish that the muscles are too fatty to be palatable. According to my own experience with that species (NISHIMURA 1960a), however, the nature of muscles appeared almost similar to those of the dealfish. Hurton (1961) stated that the muscle of the Atlantic oarfish tasted like that of the pompano, a non-fatty fish. Probably, UcHIDA (op. cit.) took erroneously as fat the soft, jelly-like substance (possibly polysaccharides) contained abundantly in muscular tissue of the taeniosome fishes. 


\section{Locomotion}

The locomotion of the taeniosome fishes has attracted so far the interests of many zoologists, not only on account of their peculiar form and unique structure, but also of a belief supported by some authors that a part of the so-called "sea-serpent" stories might be attributed to a member of this group, i. e. the oarfish (cit. GoODE \& BEAN 1895). Various opinions have been expressed as regards the method of locomotion in the oarfish (NISHIMURA 1961); and it may not be inappropriate, in this connection, to try a short discussion on the locomotory behavior of its allied species, the dealfish.

It is needless to say that direct observations on the behavior of any mesoor bathypelagic fishes under their natural habitat are very difficult. Therefore, we are apt to speculate on it on the basis of their morphological and physiological characteristics; and without doubt a number of peculiar features found in both morphological and physiological make-ups of the dealfish may play significant roles in its locomotory behavior.

The most important point to be considered first is the absence of swimbladder in the dealfish. Notwithstanding this fact, it keeps a rather small density, just within $1.1 \%$ of neutral buoyancy. But yet it is inevitable that the dealfish has to maintain some appropriate effort continuously against sinking if the animal is not to fall down to the bottom of the ocean. Is the dealfish maintaining really any effort against the sinking? If so, in what way is the effort carried out? My attention is now focused on the well-developed and lengthwise-extended dorsal fin of this species with the rays articulated to the interspinous bones in a peculiar way and accompanied with remarkably developed levator and flexor muscles. These muscles are composed of "red muscle", whereas all others, including the lateral and pectoral-fin muscles, are "white". It is generally accepted that the red muscle acts just slowly and weakly but endures continuous working for a prolonged time, while the white muscle works vigorously but for a short time (NATORI 1951). And, actually various physiological and biochemical differences between the red (or dark) and white muscles of fish have been demonstrated by many researchers (MiYAUCHI 1915 ; Matsui \& Fukayama 1916; Okuda 1917; Parks \& Rose 1933: Ogisu 1937; Shewan 1951; Yanase 1952; Matsuura et al. 1953; Matsuura \& Hashimoto 1954 ; etc). It seems very likely that the dealfish will always move the dorsal fin sideways to generate an incessant undulation to propel the animal, and that a part or the vertical component of the kinetic energy thus liberated will contribute to counterbalance the slow sinking. To make the above-mentioned motions effectual, the dealfish must keep an antero-posteriorly inclined posture with the head obliquely upward when it is slowly falling down or poising in water, in a similar way as presumed already for the oarfish (Text-fig. 5; Nishimura 1961). This remains, however, to be proved. Anyhow, the peculiar 
manner of articulation between the fin-rays and the interspinous bones may safely be considered as a modification adapted to the continuous work.

Another question is whether the dealfish makes use of flexure of the trunk and tail for locomotion or not. Once, Schlesinger (1911) assumed that the taeniosomes might undulate the body in a large amplitude somewhat like the leptocephali of apodal fishes and this anguilliform movement might be the

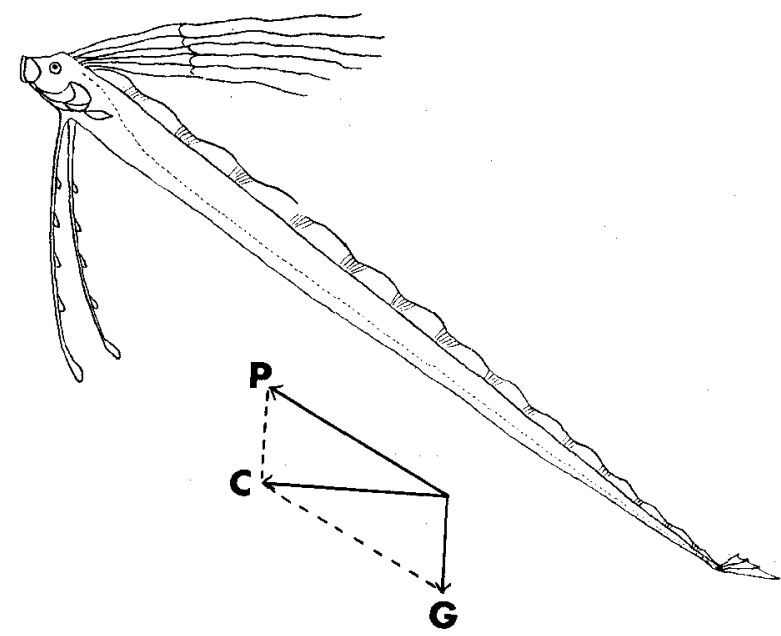

Text-fig. 5. The possible posture assumed by the oarfish when it is normally swimming in its natural habitat (After Nishimura 1961).

As the fish lacks a gas-filled swimbladder and any appreciable amount of fat in tissues as in the dealfish, it must have a larger density than sea water unless any mechanism of reducing density is secured. And the fish will continue to sink through the surrounding water. During the fall, the fish will take an antero-posteriorly inclined posture with the head obliquely upwards owing to the braking effect of the long filamentous dorsal and pelvic fin-rays and the horizontally-inserted pectoral fins. A slow progress by incessant undulation of the long dorsal fin may be the locomotion normally found in a calm state. In this posture, the obliquely upward movement $(P)$ is counterbalanced with the sinking (G) so as to keep the vectorially composed displacement (C) nearly horizontally, thus the fish may be able to maintain roughly the constant depth in a middle layer of the ocean.

principal type of locomotion for the group. In considering the possibility of this type of locomotory behavior for the dealfish, a serious attention is to be paid to the nature of the trunk musculature: the lateral musculature of this taeniosome species is very watery and soft, and composed of "white muscle"; moreover it is a remarkable feature that lateral muscles consist of respectively a series of longitudinally greatly elongated muscle-cones or myomeres, and 
only two or three cones are telescoped into one another. This is in a sharp contrast to the scombroid fishes with active migratory ability, in which the lateral musculature is solid, thick and composed of "red muscle", and the fitting of muscle-cones is very dense (KAFUKU 1950). Further, there are two other prominent features in the structure of the dealfish: the poorly ossified and fragile vertebrae and the improportionately well-developed connective tissues in dermis and intermuscular septa. These seem to inhibit a vigorous undulation of the body in a large amplitude*. If such an undulation is to occur, it will last for only a limited length of time and cannot be a pincipal locomotion impetus in the present animal, because the "white" lateral muscles will soon be exhausted. Thus, it may be safely supposed that the occurrence of anguilliform type of locomotion is confined in this fish only to the emergencies to escape from enemies or unfavorable conditions or to pursuit swiftly-swimming food animals.

The posteriorly increasing trend of the vertebra size presents another interesting problem. The teleosts which are known to perform typical anguilliform or nearly anguilliform body movements, such as Apodes, Anacanthini, Trichiuridae, Plotosidae, Blennidae, etc., have usually vertebrae rapidly diminishing the size toward the tail (see the figures of axial skeleton prepared by HotTA 1961 and TAKAHASH 1962), or in other words they show a prominent pre-modal type of the vertebral length curve (YAMAda 1961). The comparison of this type of the vertebral length curve with the remarkably post-modal type of the curve of the dealfish (Text-fig. 2) seems to lead to the conclusion that the present taeniosome species is not provided with a flexible tail adapted to the continuous and smooth movements so characteristic in anguilliform swimmers. YAMADA (op. cit.) gives the vertebral length curves for not less than 100 species of fishes, mainly Perciformes, and we may find that the curve for Aluterus (=Alutera) monoceros, the filefish, resembles most closely to that of the dealfish, though the resemblance is by no means perfect; and it may be of particular interest to note that the filefish is not an anguilliform swimmer but a sluggish creature showing a balistiform movement maintained by slow undulation of the dorsal and anal fins inserted respectively on the opposite sides on the posterior half of the body**.

There are a. few persons who have ever had an opportunity to observe

* Excessive bending will damage the body of the dealfish, especially the posterior portion, breaking down the vertebral column and tearing off the dermis and intermuscular septa on a transverse plane. Such damages were frequently observed on the taeniosome fishes by various authors, KURODA (1947), TsudA (1959, and personal communication of April 1962), WALTERS (1959) and HuTTON (1961).

** KojIma (1959) reports an interesting habit of Aluterus monoceros; when the fish is found solitarily under any floating objects, it usually holds the body vertically with the tail end upward, poising in water without shifting the situation. The same behavior was also observed on a related species, A. scriptus (=Osbeckia scripta) by UcHIDA (1927) and KoJIMA (1959). 
the dealfish swimming in the sea or in an aquarium; and it may be very useful to reproduce here some of the records of their observations to see whether the supposition presented above agrees with the actual observations or not. Of course it must be kept in mind that the behaviors observed on the individuals accidentally brought up to the surface layer of the sea or those deposited in the artificial circumstances might differ from those under a natural habitat of the species.

Messrs. H. Fukataki and M. Okiyama of the Japan Sea Regional Fisheries Research Laboratory have observed the behaviors of three individuals of this taeniosome species entrapped in a set net on the coast of Sado Island. Their observations tell as follows:

The fish swam in a considerable speed, with a conspicuous wavy movement along the dorsal fin. The undulation of body was also noted, though it was by no means remarkable. The fish continued the undulation of the dorsal fin for a while even after it was brought aboard the boat. Swimming was almost straight-on, the longitudinal axis of the body probably being kept hori. zontal and delicate maneuvering seemed impossible for the fish. No struggles were performed when the animal was brought out of water.

Mr. Chuichi Araga of the Misaki Aquarium near Osaka (now at the Aquarium of the Seto Marine Biological Laboratory) kindly informed me in his personal communication of January 1962 his observations on a single individual caught at Kada (加太), Wakayama Prefecture, and then kept alive in his aquarium for only six hours. He says :

Immediately after released into the aquarium, the fish swam for a while in an ordinary posture, but soon it settled down on the bottom by one of the lateral sides. Thereafter, the animal kept that pose until death retaining the wavy motion of the dorsal fin throughout. No sign of body undulation was observed in the aquarium, though the person who caught the specimen stated that the fish had been swimming just under the sea surface by undulating the body.

In this connection, Nilsson's observation (1855) on the behaviors of Trachipterus arcticus (BRÜNNICH), a North-Atlantic congener, seems particularly interesting. He says that the fish comes on the sandy shelving shore at flood tide and is often left when waves retreat, that on the bottom of 2 or 3 fathoms deep it moves with one lateral side obliquely toward the ground, and that after all it is a slow swimmer. Nilsson's opinion is that it behaves like a flatfish!

The above-mentioned observations agree in the point that the dorsal fin continues persistently the prominent undulating movement even when the fish is much demoralized by lowered pressure or rough water motion which has probably brought the fish up to the sea surface; and this seems to render a convinced support to the view that the principal role is played by the dorsal fin in the locomotory behavior of the dealfish. The fact that the fish sinks to and lies on the bottom shows clearly that the specific gravity of the fish is larger, even slightly, than that of the sea water. The anguilliform movement, on the other hand, is considered to be an effort to get rid of the unusual 
circumstances of the shallow waters where it has been thrown into accidentally; but this can not last for longer time, it will be exhausted and washed ashore easily at flood tide.

\section{Food and Feeding Habit}

In the male specimen, any food contents of the digestive tract could not be identified. But in the female specimen, a beak and a pair of eye-lenses of a squid and another pair of minute eye-lenses possibly of a teleost were found in the stomach ; the soft body parts of these animals had been completely digested, and there were no other food materials identified throughout the guts. Although definite identification of those food animals was impossible, it was certain that both of them were small-sized individuals*.

As mentioned previously, the gill-rakers are rather poorly developed and built roughly in the dealfish; they consist of several to a dozen short, cartilaginous rods arranged in double rows along the inner margin of respective gill-arches, and the rods themselves are provided each with a few, sharply pointed spinules on the inner surface of the distal half (Text-fig. 6). These somewhat degenerated or rudimentary gill-rakers of the dealfish present a striking contrast to those of the oarfish, which consist of a considerably large number of long and slender rods closely set to filter plankton out of water (MORI 1956; NishimUra 1960a). It is also to be noted that the dealfish has solid jaws with several hard, sharp teeth set on premaxillary, dentary, vomer and palatine, all pointed toward the pharynx. Especially, enormously developed and backward-pointed upper pharyngeal teeth are noteworthy; some of them assume a powerful canine appearance. Such structures and arrangements of the jaws and teeth are most probably effective for seizing more or less active preys. Contrarily, the oarfish has soft and fragile jaws without any dentition but merely upper pharyngeal bones studded with numerous minute pointed teeth (Nishimura 1960a). Thus, the oarfish principally feeds upon zooplankton, while the dealfish is considered rather to be adapted to prey upon creatures

\footnotetext{
* The structure of the squid beak was closely related to that of the member of the family Enoploteuthidae. If this supposition is correct, the ingested squid should be $5-6 \mathrm{~cm}$ in mantle length. The squids which fall within this size range in adult stage and occur abundantly in middle layer of the Japan Sea are Watasenia scintillans (BERRY) and Enoploteuthis chunii IsHIKAwA. These luminescent squids are both known to form important food items for various deep-water fishes such as Theragra chalcogramma, Hippoglossoides dubius, Malacocottus gibber, Squalus acanthias suckleyi and so on (TABATA 1958; WATANABE et al. 1958). The ingested teleost was estimated to be $3-4 \mathrm{~cm}$ in body length; this suggests that the fish might be Maurolicus muelleri japonicus IsHIkAwA of the family Gonostomatidae which is of nearly the same size in adult stage and profuse at the mid-depths of the Japan Sea. This small-sized and luminescent teleost is known also to play a comparably important role in the economy of mesopelagic community in the southeastern part of the marginal sea (NISHIMURA 1957, 1960b, unpublished MS.; WATANABE et al. 1958).
} 
of a little larger size and somewhat greater mobility, namely small-sized fishes or cephalopods. The feeding habit of the oarfish has actually been cleared out by Terao (1931), Mori (1956) and Nishimura (1960a).

Through the biological and acoustical studies made on the so-called deep scattering layers (D. S. L.), an existence of abundant dense populations of small-sized nektonic animals, most probably pelagic fishes possessing a gas-filled swimbladder (Marshall 1951; Tucker 1951; Hersey \& Backus 1954; Hersey, BACKus \& HeLlwig 1961), at the midwater zone of the ocean is nowadays an unquestionable fact. And it is very possible that these animals offer a rich food to the dealfish and its related species. I suggested that the dealfish as well as the oarfish might be inhabiting the Central Water Mass of the oceans (Nishimura 1962a, 1962b). If this is true, it may be concluded that the natural

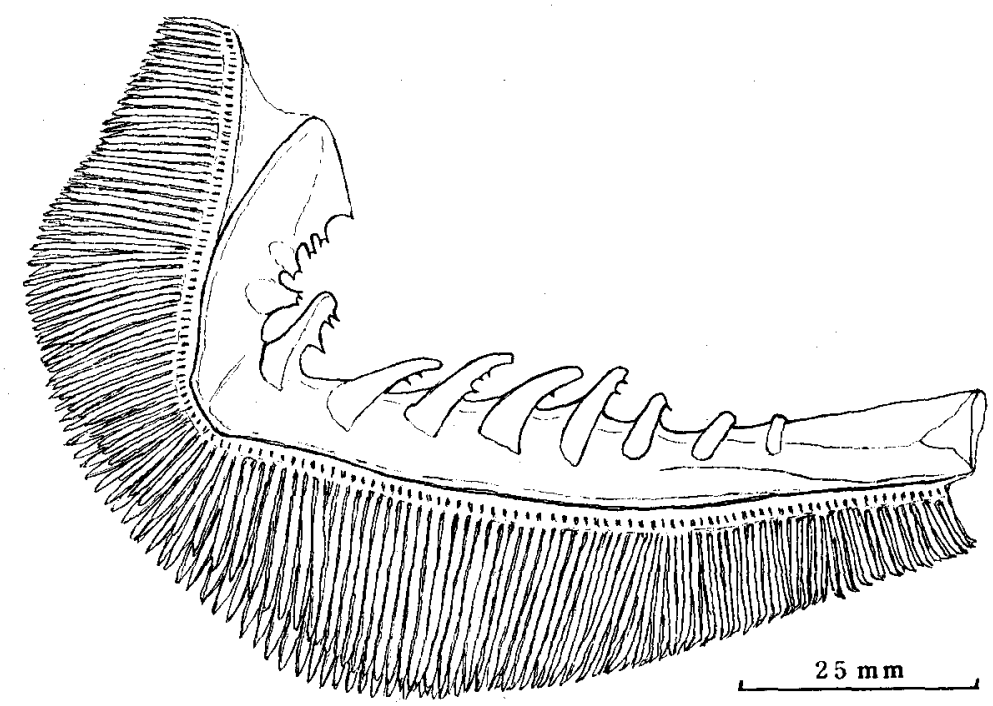

Text-fig. 6. Outside of the first gill-arch of the dealfish.

habitat of these taeniosomes is within the range from $100-200 \mathrm{~m}$ to $500-800 \mathrm{~m}$ or further down to $1000 \mathrm{~m}$; this is based on the schema of hydrographic structures of the world oceans given by Sverdrup, Johnson \& Fleming (1942), and the range just corresponds to the limit of occurrences of the D. S. L. by day (Marshall 1951; Dietz 1962).

\section{Parasites}

A tetraphyllidean plerocercoid larva of the family Phyllobothriidae Braun, 1900, and a larval nematode of the family Heterocheilidae RAILLIET \& HENRY, 1915, were collected from the dealfish. Their number and location of occurrences in respective host individuals are shown on Table 5 . No metazoan 
Table 5. Occurrences of helminth parasites in the dealfish.

\begin{tabular}{l|c|c|c|c}
\hline & \multicolumn{2}{|c|}{ Plerocercoid larva } & \multicolumn{2}{c}{ Larval nematode } \\
\cline { 2 - 5 } & Number & Location & Number & Location \\
\hline \multirow{2}{*}{ Male specimen } & 19 & Duodenum and intestine & 1 & Peritoneal membrane \\
Female specimen & 29 & Duodenum and intestine & None & - \\
\hline
\end{tabular}

parasites other than these two helminths were detected by examinations of the gills, body muscles and other internal organs.

Plerocercoid larva (Text-fig. 7)

Plerocercoids were found free in the duodenum and intestine, some of them penetrating into pyloric caeca. They were greatly variable in size, ranging from a few millimeters to about $20 \mathrm{~mm}$ or more in length, and they may reach more than $30 \mathrm{~mm}$ when fully extended. The plerocercoids taken out of their habitat were sluggish, scarcely showing any sign of crawling movement but

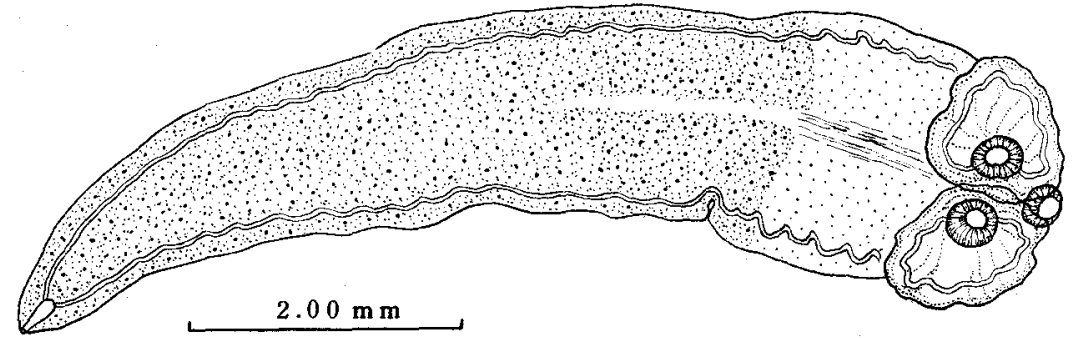

Text-fig. 7. Tetraphyllidean plerocercoid from the digestive tract of the dealfish. Drawn from a specimen mounted in Canada balsam.

for bothridia and rostellum which moved actively and rhythmically, and easily held themselves on the substratum by bothridia. They are milky white in color, but sometimes tinged red in the median part of the pars antica scolecis.

The four bothridia with crumpled margin are attached to the scolex by a more or less broad base in dorsal and ventral pairs. An apical sucker is present at the apex of the scolex. A simple accessory sucker is located on each bothridium at the anterior end. A loop of the excretory system enters each bothridium, running there parallel to the margin. The measurements of various body parts of the six specimens held under a cover glass are shown on Table 6 .

This is the first record of a tetraphyllidean larva from Trachipterus ishikawai JoRDAN \& SNYDER. The characteristic structure of the scolex makes us refer the present plerocercoid to the family Phyllobothriidae. A very similar form was described by Hutron (1962) from Regalecus glesne (Ascanius), a related species of the dealfish from the Gulf of Mexico, and was referred to the genus Phyllobothrium VAN BENEDEN, 1850. It is unknown whether these two larval 
Table 6. Measurements of the plerocercoid larvae (in $\mathrm{mm}$ ).

\begin{tabular}{c|c|c|c|c|c}
\hline $\begin{array}{c}\text { Specimen } \\
\text { No. }\end{array}$ & $\begin{array}{c}\text { Total } \\
\text { length }\end{array}$ & $\begin{array}{c}\text { Pars } \\
\text { antica }\end{array}$ & $\begin{array}{c}\text { Diameter of } \\
\text { apical sucker }\end{array}$ & Bothridium & $\begin{array}{c}\text { Diameter of } \\
\text { accessory sucker }\end{array}$ \\
\hline 1 & 2.8 & - & 0.14 & $0.36 \times 0.48$ & 0.18 \\
2 & 3.1 & 1.01 & 0.18 & $0.65 \times 0.71$ & 0.21 \\
3 & 3.9 & 1.13 & 0.27 & $0.65 \times 0.68$ & 0.30 \\
4 & 6.9 & 1.73 & 0.30 & $0.83 \times 1.13$ & 0.30 \\
5 & 8.5 & 2.26 & 0.29 & $0.95 \times 1.31$ & 0.30 \\
6 & 10.1 & 2.38 & 0.32 & $0.89 \times 1.25$ & 0.32 \\
\hline
\end{tabular}

forms belong to the same species or not.

Under the name of Scolex pleuronectis MÜLLER, 1788 or S. polymorphus RudolPHI, 1819 (Southwell 1925 considers the latter as a synonym of the former), a great number of similar larval forms have been described from various kinds of cephalopods, marine and anadromous cyclostomes and fishes (recent references are: Dollfus 1923a, 1923b, 1929, 1931, 1936; Yamaguti 1934; Schulman \& Schulman-Albova 1953 ; Zhukov 1960; Strelkov 1960; etc.), and it is generally conceived that they may develop into a number of different species in the gut of the definitive host (Wardle \& McLeod 1952). Although a complete life cycle is not yet known in any tetraphyllideans, it is supposed on a priori grounds that the first larval stage of the present phyllobothriid cestode might occur in a small crustacean and the adult might be parasitic in a selachian. Larval nematode

A single nematode larva was found encapsulated in a flat spiral on the peritoneal membrane of the host. This larva, considerably large-sized, has neither ventricular appendix nor intestinal caecum ; the oesophagus is musculoglandular, i.e. the ventral part is muscular while the dorsal part is glandular; the ventriculus is quite glandular and massive; the excretory pore is situated at the level of the nerve ring. These characteristics seem to assign the present larva to the genus Eustoma VAN BENEDEN, 1870 (= Anacanthocheilus WÜLKER, 1929 ; Pseudanisakis YamaguTI, 1941).

The body is ca. $28.5 \mathrm{~mm}$ long, the greatest width $0.49 \mathrm{~mm}$ at the posterior third of body length. The apico-ventral boring tooth is inclined ventrally. The nerve ring is located $0.32 \mathrm{~mm}$ apart from head end. The oesophagus is slightly enlarged posteriorly, $2.14 \mathrm{~mm}$ long (exclusive of ventriculus), $0.12 \mathrm{~mm}$ and $0.20 \mathrm{~mm}$ wide respectively near the anterior and posterior ends. The ventriculus is $1.25 \mathrm{~mm}$ long and $0.28 \mathrm{~mm}$ wide. The tail $0.10 \mathrm{~mm}$ long, rounded and tapering abruptly with a minute terminal spike.

This is the larval nematode commonly found in various marine teleosts, particularly in Gadidae, and there have been contradictory views among authors as to its taxonomical position: some authors referred it to the genus Anisakis 
Dujardin, 1845, but here I followed the opinion of WülKer (1930) and KAHL (1938).

The adult forms of the genus Eustoma are parasitic in a selachian; and in the neighboring waters of Japan, only a single species of the genus, E. (=Pseudanisakis) rajae (YAMAgUt, 1941) is reported from Raja kenojei Müller \& Henle collected on the Pacific side.

\section{Summary}

1. Descriptions are given on the external characters and gross internal anatomy of the two specimens of dealfish, Trachipterus ishikawai JoRDAN \& SNYDER, a taeniosome teleost living in a mesopelagic zone of the ocean, caught at Sado Island in the eastern Japan Sea.

2. For one of the specimens, the body density is calculated to be 1.037 and the sinking factor to be 1011. Thus, the fish would fall down through the water unless an appropriate effort is made against the sinking. Nevertheless, this density value is notably small for the fish without swimbladder, since this bladderless fish may be able to maintain itself within $1.1 \%$ of neutral buoyancy.

3. Chemical analyses of trunk muscles and vertebral bones of the fish, the principal constituents of the body of the present species, reveals that these organs contain larger amount of water but lesser amount of minerals than in typical neritic or epipelagic teleosts and that the contents of proteins and crude fat of the muscles in particular are exceedingly low. The dealfish seems to maintain its small value of density by a reduced muscular development and a poor ossification of the skeletal system.

4. The well-developed dorsal fin with a peculiar mode of articulation between the rays and the interspinous bones and well-developed levator and flexor muscles attached to the rays alludes that the incessant undulation of the dorsal fin might be the most significant impetus for the dealfish to keep its normal posture. And probably, at least a part of the kinetic energy thus liberated might counteract the sinkng. A vigorous undulation of the trunk and tail might occur but only in emergencies; such a movement will not last long before the fish will be exhausted, because the lateral musculature is composed entirely of "white muscle", whereas the muscles attached to the dorsal fin-rays are made of "red muscle".

5. The structures of the food collecting and seizing apparatus and the results of examinations of the stomach contents indicate that small-sized nektonic animals might be principal diets of the dealfish. The natural habitat of the fish is supposed on the basis of distribution of the food animals.

6. A plerocercoid of the family Phyllobothriidae and a larval nematode of the family Heterocheilidae are described; both of them are respectively the first records for the dealfish. 


\section{REFERENCES}

AxitA, U. K. 1936. Studies on the physiology of the swimbladder. J. Fac. Sci., Imp. Univ. Tokyo, Ser. 4 (Zool.), 4 : 111-135.

BLACK, V. S. 1948. Changes in density, weight, chloride and swimbladder gas in the killifish, Fundulus heteroclitus, in fresh water and sea water. Biol. Bull., 95: 83-93.

Delaroche, F. E. 1809. Observations sur la vessie aérienne des poissons. Ann. Mus. Hist. nat. Marseille, 14 : 184-217, 245-289.

Denton, E. J. \& MARshall, N. B. 1958. The buoyancy of bathypelagic fishes without a gas. filled swimbladder. J. mar. biol. Ass. U. K., $37: 753-767$.

Dietz, R. S. 1962 . The sea's deep scattering layers. Sci. Amer., 1962 (8) : 44-50.

Dollfus, R. PH. 1923a. Énumération des cestodes du plancton et des invertébrés marins. Plancton, Coelentérés, Echinodermes, Vers, Mollusques gastéropodes et lamellibranches. Ann. Parasitol. humaine et comparée, $1: 276-300$. 1923b. Enumération des cestodes du plancton et des invertébrés marins. Mollusques céphalopodes et Crustacés. Ann. Parasitol. humaine et comparée, 1 : 363-394. 1929. Addendum à mon "Énumération des cestodes du plancton et des invertébrés marins." Ann. Parasitol. humaine et comparée, $7: 325-347$.

1931. Nouvel addendum à mon "Énumération des cestodes du plancton et des invertébrés marins." Ann. Parasitol. humaine et comparée, $9: 552-560$.

1936. Cestodes des invertébrés marins et thalassoïdes. In C. Joyeux \& J. C. BAER : Cestodes. Faune de France, vol. 30 (Paris, 1936) : 508-539.

EbiNA, K. 1934. [A dealfish collected in Shizuoka Prefecture]. Rakusui Kaishi, 29: 530-532. In Japanese.

Goode, G. B. \& BEAN, T. H. 1895. Oceanic ichthyology. Spec. Bull. U. S. nat. Mus., Washington. $\mathrm{xxxv}+553$ pp., 123 pls.

Handbook of Fisheries Sciences (3rd ed.) 1925. Edited by Dai Nippon Suisan Kai, Tokyo. In Japanese.

HERSEY, J. B. \& BACKUS, R. H. 1954. New evidence that migrating gas bubbles, probably the swimbladders of fish, are largely responsible for scattering layers on the continental rise south of New England. Deep-Sea Res., 1: 190-191.

_ — \& Hellwig, J. 1961. Sound-scattering spectra of deep scattering layers in the western North Atlantic Ocean. Deep-Sea Res., $8: 196-210$.

HONDA, I. 1960. [Trachipterus ishikawae JoRdAN \& SNYDER, a rare fish]. Saishu to Shiiku, $22: 114$. In Japanese.

HotTA, H. 1961. Comparative study of the axial skeleton of Japanese Teleostei. Nôrin Suisan Gijutsu Kaigi, Tokyo. 167 pp., 69 pls. In Japanese.

Hutton, R. F. 1961. A plerocercoid (Cestoda: Tetraphyllidea) from the oar-fish, Regalecus glesne (AscanIUS), with notes on the biology of the oar-fish. Bull. mar. Sci. Gulf \& Carib., 11 ; $309-317$.

IwAI, T. 1959. The fat-containing swim-bladder of the stomiatoid fish, Yarrella elongata MATSU BARA. Sci. Rep. Yokosuka City Mus., (4) : 1-4.

Jones, F. R. H. 1951. The swimbladder and the vertical movements of teleostean fishes. I. Physical factors. J. expr. Biol., $28: 553-566$.

1957. The swimbladder. In M. E. BRown (ed.): The physiology of fishes, vol. 2 (New York, 1957) : 305-322.

\& MARShat L, N. B. 1953. The structure and functions of the teleostean swimbladder. Biol. Revs., 28 : 16-83.

JORDAN, D. S. \& SNYDER, J. O. 1901. Descriptions of nine new species of fishes contained in museums of Japan. J. Coll. Sci., Imp. Univ. Tokyo, 15: 301-311.

KafuKU, T. 1950. "Red muscles" in fishes. I. Comparative anatomy of the scombroid fishes of Japan. Jap. J. Ichthyol., $1:$ 89-100. In Japanese. 
KAHL, W. 1938. Nematoden in Seefischen. II. Erhebungen über den Befall von Seefischen mit Larven von Anacanthocheilus rotundatus (RuDoL.PHI) und die durch diese Larven hervorgerufenen Reaktionen des Wirtsgewebes. Zeitschr. Parasitenk., 10: 513-534.

Kamita, T. 1962. Visits by unusual aquatic animals to the sea coasts of San-in District, Japan Sea. San-in Bunka Kenkyu Kiyo, (2) : 1-35. In Japanese.

Kamohara, T. 1950. Description of the fishes from the provinces of Tosa and Kishu, Japan. Kôchi-Ken Bunkyo Kyokai, Kochi. In Japanese.

KoJima, Sh. 1959. [On the fishes that swim upside-down]. Monthly Rept. Shimane Pref. Fish. Exper. Sta., 4 (2) : 22. In Japanese.

Kuroda, N. 1947. Additions to the catalogue of the fishes of Shizuura, Suruga and the vicinity (VIII). Seibutu, Suppl. (1): 25-31. In Japanese

1957. Additions and corrections to the fishes of Suruga Bay (XIV). Dobutsugaku Zasshi, 66 : 461-463. In Japanese.

Love, R. M. 1957. The biochemical composition of fish. In M. E. Brown (ed.) : The physiology of fishes, vol. 1 (New York, 1957) : 401-418.

Lowndes, A. G. 1941. The displacement method of weighing living aquatic organisms. J. mar. biol. Ass. U. K., 25 : 555-574.

MAGNAN, A. 1929. Les caractéristiques géométriques et physiques des poissons: Aves contribution à l'étude de leur équilibre statique et dynamique. Ann. Sci. nat. Zool., 12: 5-133.

Marshall, N. B. 1950. Air bladder structure and vertical distribution in deep-sea fishes. Challenger Soc. Ann. Rept., 3 (2), 26 pp.

1951. Bathypelagic fishes as sound scatterers in the ocean. J. mar. Res., 10: 1-17.

Matsubara, K. 1947. Trachipterus ishikawae Jordan et Snyder. In Ill. Encycl. Fauna Japan (rev. ed., Tokyo, 1947) : 458. In Japanese.

1955. Fish; Morphology and hierarchy. 3 vols. Ishizaki Shoten, Tokyo. In Japanese.

MATSUI, H. \& FUKAYAMA, Y. 1916. [Comparison of nitrogen compounds between ordinary meats and "chiai" meats]. J. Imp. Fish. Inst., 12: 37-45. In Japanese.

MAtsuUra, F., BABA, H. \& MoRI, K. 1953. Chemical studies on the red muscle ("chiai") of fishes. I. Occurrence of arginase in the red muscle of fishes. Bull. Jap. Soc. sci. Fish., 19: 893-898. In Japanese.

\& Hashimoto, K. 1954. Chemical studies on the red muscle ("chiai") of fishes. II. Determinations of the content of hemoglobin, myoglobin and cytochrome $\mathrm{C}$ in the muscles of fishes. Bull. Jap. Soc. sci. Fish., 20: 308-312. In Japanese.

Mishio, T. 1936. [Some deep-sea creatures from Suruga Bay]. Suisan Gakkwai Ho, $7: 127-129$. In Japanese.

MiYaUchI, S. 1915. [Chemical studies on the "chiai" meat]. Nô-Gakkai Ho, (154): 401-413. In Japanese.

MORI, T. 1952. Check list of the fishes of Korea. Mem. Hyogo Univ. Agr., 1 (3): 228 pp.

1956. Note on a rare fish Regalecus russellii (SHAw), Regalecidae, from Southern Japan Sea. Sci. Rept. Hyogo Univ. Agr., 2 (2) Nat. Sci. : 33-36. In Japanese.

NATORI, R. 1951. [Muscular physiology]. Maruzen, Tokyo. In Japanese.

Nilsson, S. 1855. Skandinavisk fauna. Fjerde delen: Fiskarna. Lund.

Nishimur.A, S. 1957. What is the spawner of the so-called "Macrurus egg" from the adjacent waters to Japan? Ann. Rept. Jap. Sea reg. Fish. Res. Lab., (3): 1-11. In Japanese.

1960a. A record of Regalecus russellii (SHAw) from the Sado Straits in the Japan Sea. Ann. Rept. Jap. Sea reg. Fish. Res. Lab., (6) : 58-68.

1960b. Alaska pollacks devouring the pearlsides. Saishu to Shiiku, 22: 87-88. In Japanese.

1960c. Visits by unusual aquatic animals to the sea coasts of Niigata Prefecture, Japan Sea, in the winter of 1959-60. Saishu to Shiiku, $22: 213-216$. In Japanese. 
Nishimura, S. 1961. [On the locomotion of the oar-fish]. J. oceanogr. Soc. Jap., $17: 215-221$. In Japanese.

1962a. Recent increase in the occurrence of the deal-fish in adjacent waters to Japan. Bull. Jap. Sea reg. Fish. Res. Lab., (10): 51-58.

1962b. Records of the oar-fish in Japanese waters, with notes on some aspects of

its distribution. Sci. Rep. Yokosuka City Mus., (7) : 11-22. In Japanese. (Unpublished MS). The zoogeographical aspects of the Japan Sea.

\& Mizusawa, R. 1962. Exotic marine animals caught off Niigata Prefecture, Japan

Sea, during the winter of 1960-61. Saishu to Shiiku, 24 (3):32-35. In Japanese.

OGISU, S. 1937. Über den Glykogengehalt sog. "Tiai" bei Pisces. Dobutsugaku Zasshi, 49 : 251-255. Im Japanischen.

OKudA, Y. 1917. [Chemistry of the "chiai" meat]. Tokyo Kagaku Kai-Shi, 38: 854-897. In Japanese.

PARKs, T. B. \& Rose, E. R. 1933. Copper, iron and manganese content of fish. J. Nutrition, $6: 95-98$.

Plattner, W. 1941. Etude sur la fonction hydrostatique de la vessie natatoire des poissons. Rev. suisse Zool., 48 : 201-336.

Schlesinger, G. 1911. Die Locomotion der taënioformen Fische. Zool. Jahrb. (Abt. Syst.), 31 : 469-490.

Schulman, S. S. \& Schulman-Albova, R. E. 1953. [Parasites of fishes of the White Sea]. Izb. Akad. Nauk SSSR, Moskva i Leningrad. In Russian.

ShewAN, J. M. 1951. The chemistry and metabolism of the nitrogenous extractives in fish. Biochem. Soc. Symp. Cambridge Engl., (6) : 28-48.

Southwell, T. 1925. A monograph on the Tetraphyllidea. Mem. Liverpool School Tropical Medicine (N. S.), (2) : $368 \mathrm{pp.}$

STrelkow, J. A. 1960. Endoparasitic worms of marine fishes of east Kamchatka. Trudui Zool. Inst. Akad. Nauk SSSR, (28): 147-196. In Russian.

Sverdrup, H. U., Johnson, M. W. \& Fleming, R. H. 1942. The oceans; Their physics, chemistry, and general biology. Prentice-Hall, New York.

TABATA, K. 1958. [Studies on the exploration of fishing grounds based on the D.S.L.] Repts. Invest. Exploit. Tshushima Current, (3) : 259-262. In Japanese.

TAKahashI, Y. 1962. Study for the identification of species based on the vertebral column of Teleostei in the Inland Sea and its adjacent waters. Bull. Naikai reg. Fish. Res. Lab., (16): 1-74, 122 pls. In Japanese.

TAYLOR, H. F. 1921. Airbladder and specific gravity. Bull. U.S. Bureau Fish., 38: 121-126.

TERAO, A. 1931. [Strange animals of the deep sea]. In Umi no Kyôi (Kagaku Gaho Sha, Tokyo, 1931). In Japanese.

Tomiy ama, I. \& ABE, T. 1958. [Pisces and Cyclostomata]. In Encycl. Zool. Ill. Col., vol. 2 (Tokyo, 1958) : 1-306. In Japanese.

Tsuchiya, Y., Hata, M., Asano, M., Takahashi, I., Nomura, T. \& Suzuki, Y. 1953. Biochemical studies on skipper (Cololabis saira). I. General components. Bull. Jap. Soc. sci. Fish., 19: 513-517. In Japanese.

TsudA, T. 1959. ["Oiran" or taeniosome fishes]. Personal circulation. Shin-Minato, Toyama Pref. In Japanese.

TUCKER, G. H. 1951. Relation of fishes and other organisms to the scattering of underwater sound. J. mar. Res., $10: 215-238$.

UCHIDA, K. 1927. [On the larvae and habits of several species of Monacanthidae]. Dobutsugaku Zasshi, 39 : 161-178. In Japanese.

1956. [Fish-Man's daily life and fishes--]. Keio Tsushin, Tokyo. In Japanese.

WALters, V. 1959. The sea serpent that is a fish. Sea Frontiers, Bull. internat. oceanogr. Found., 5 (2) : 102-104. 
WARDLE, R. A. \& MCLEOD, J. A. 1952. The zoology of tapeworms. Univ. Minnesota Press, Minneapolis.

Watanabe, T., Ito, K., Kobayashi, T., Nazumi, T. \& YoshiokA, S. 1958. A study on the structure of bottom fish communities at trawling ground, off Port Tsuiyama in Hyogo Prefecture. Bull. Fish. Expr. Sta. Hyogo-Ken, (9):1-20. In Japanese.

Wülker, G. 1930. Ueber Nematoden aus Nordseetieren I-II. Zool. Anz., 87 : 293-302, 88: 1-16.

YAMADA, T. 1961. On the vertebral length curve of teleosts. Bull. Jap. Soc. sci. Fish., 27 : 510-515. In Japanese.

YAmagutI, S. 1941. Studies on the helminth fauna of Japan. Part 33. Nematodes of fishes II. Jap. J. Zool., 9 : 343-396, Pls. 4-6.

YANAI, T. 1950. The fishes of the Sanin district. Dobutsugaku Zasshi, 59: 17-22. In Japanese.

YANASE, M. 1952. Studies on the vitamin $B_{12}$ of aquatic animals $I$. The vitamin $B_{12}$ content of fishes (1). Bull. Jap. Soc. sci. Fish., $17: 389-392$. In Japanese.

ZHukov, E. V. 1960. Endoparasitic worms of the fishes in the Sea of Japan and South-Kuril shallow-waters. Trudui Zool. Inst. Akad. Nauk SSSR, (28) : 3-146. In Russian. 
A male dealfish, Trachipterus ishikawai JoRdan \& SNyder, $1208 \mathrm{~mm}$ in standard length, caught off Waki in the Bay of Ryotsu, Sado Island, on March 16, 1962. 
Publ. Seto Mar, Biol, Lab., XI, 1 (1963)

PLATE II

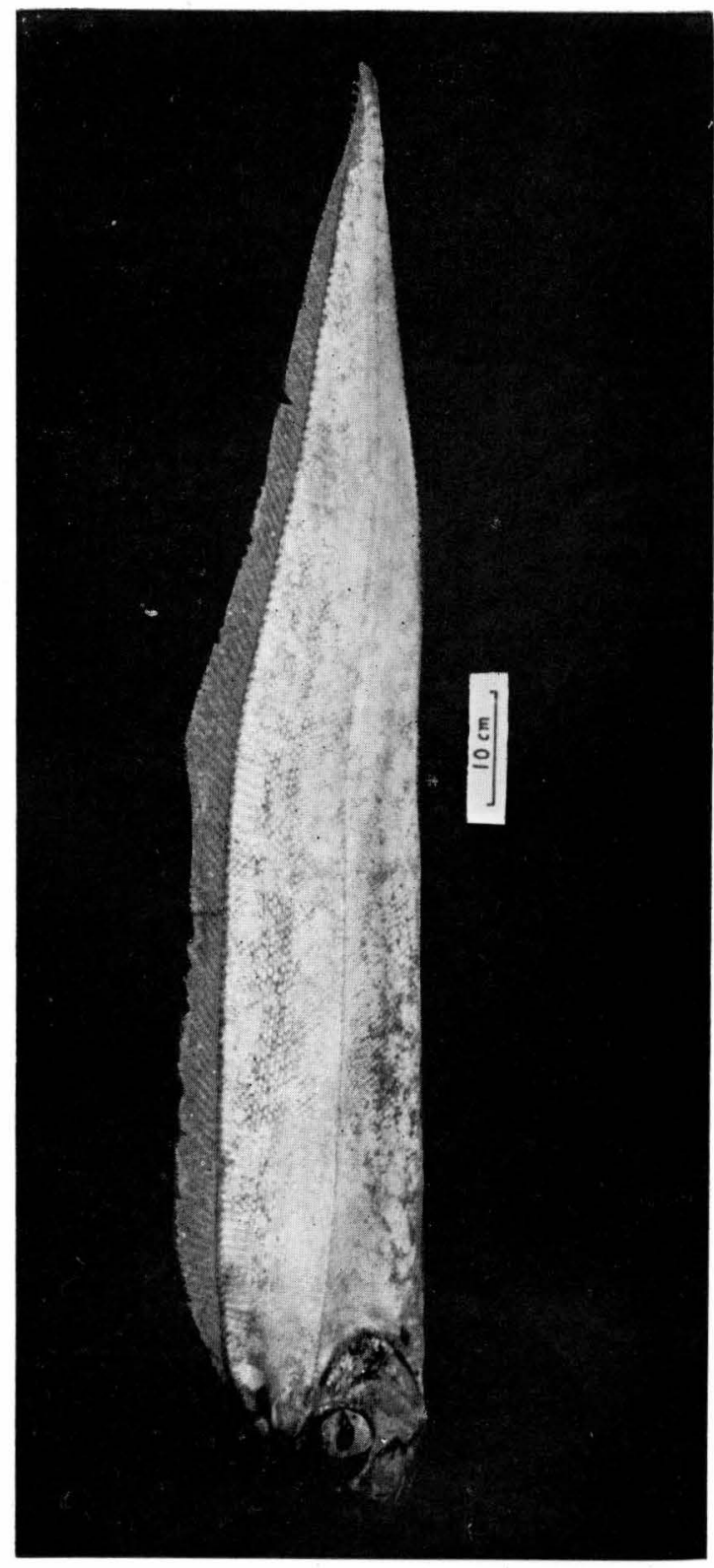

S. Nishimura: Observations on Dealfish, 